\title{
Water Resources Development / Management for Agriculture in Sri Lanka; Past and Future
}

\author{
M Y Zainudeen
}

\begin{abstract}
Water resources have been developed in Sri Lanka since the pre-Christian era, merely for irrigated agriculture. Technology development during the last century has further developed this sector for hydropower generation, domestic water supply, industry and other uses as well. Major users of surface water are irrigated agriculture, hydropower and domestic supplies while the ground water is extensively used for industry and conjunctive use in commercial agriculture. Irrigated agriculture sector uses almost $85-90 \%$, of developed water, in terms of volume, according to recent estimates. Pipe borne water facilities are provided to about 70 percent of the urban and 15 percent of the rural population and there are ample requests for more domestic water supply schemes in the rural areas in view of introducing good sanitation practices. Despite the commendable achievement in the sector during the last few decades, this sector suffers many crises and has got to face many challenges in the future.
\end{abstract}

\section{Introduction}

Natural resources (water, fertile soils) and the climate have been the main driving force for Sri Lanka to become a prominent agricultural country for known history of a few millennia. The country has a long history of hydraulic civilization and irrigated agriculture and has been named as the "Granary of the Far-East" with surplus grain production, mainly rice, staple diet of the nation. Large irrigation infrastructure constructed in the dry and intermediate zones of Sri Lanka during the first and second millennia has been the live wire of the then agriculture which has resulted in such a production. This reflects the success of the vision on food security that the rulers in the country had in achieving and maintaining selfsufficiency in rice to feed the nation.

In the post independence era too the country's policies for the economic growth and self sufficiency have always considered agriculture as a top priority strategy in view of realizing prosperity. Large investments on developing water resources in the country for agriculture, during the last century is testimony for these policies. The area cultivated rose from $200,000 \mathrm{Ha}$ in the 1960 s to $736,000 \mathrm{Ha}$ in the 2000 s throughout the country of which about $75 \%$ is under irrigated condition during both seasons. This set up has resulted in improved food production, higher employment opportunities, improved living conditions and rapid economic growth.
Despite these commendable achievements in local food production resulting from water resources development, an alarming reality is that the sector consumes large amounts of water with low productivity, creating a scarcity in the other water use sectors. Water scarcity will become more acute in the future in the absence of significant efforts to save water through enhancing the productivity of water. Although water is considered a renewable resource, it has become so depleted or contaminated in many parts of the country creating a deficiency against the ever-increasing demands, demonstrating the limitation of the renewable phenomena. The current scenario seeks an environmentally sustainable and socially acceptable framework for developing and managing water resources in the country

\subsection{Water Resources Development in Sri Lanka}

\subsection{Water Resources}

Sri Lanka has a land area of 65,560 square kilometers and the topographical features are such that a hilly terrain lies in the southern centre sloping down in all directions towards the sea. There are 103 distinct drainage basins, covering over $90 \%$ of the Island, originating

Eng. M Y Zainudeen - PG Dip in Engineering, (Morntuwa), M Sc, (Hons) (Irelnud), C Eng., I Eng.. FIESL, FIIESL Currently fiunctioning as the Deputy Chlef Secretany (Eng. Services), North Westem Provincial Counnil 
from the hills and traces to the sea in a radial pattern via the flat terrain. Sixteen of them are located in the wet zone and they are perennial, while those that are located in the dry zone are seasonal. The remainder are small coastal basins.

The Island is subjected to two monsoons, namely North East (wet season) from October to March and South East (dry season) from April to September. The Island has a wide range of climatic conditions, varying from the most wet to semi arid. Mean annual precipitation in the wet zone is around $2400 \mathrm{~mm}$ and that of the dry zone is around $1400 \mathrm{~mm}$ averaging around 2000 $\mathrm{mm}$ for the Island. It is estimated that the total amount of water received from precipitation is around 127,000 MCM/year and the mean annual run-off is around 51,300 MCM of which about one half is from the wet zone and the rest is from the dry zone.

\subsection{Water Resources Development}

\subsubsection{Background}

Sri Lanka has a very long history of hydraulic civilization, stretching as far back as $500 \mathrm{BC}$. The monastic architecture of the ancient kings, their sculpture and the ancient irrigation works reflect the refinement of their art and engineering skills in constructing irrigation systems for agricultural purposes. R L Brohier in his "Ancient Irrigation Works in Ceylon" records that in Pre-Christian times, Ceylon had attained the idea of controlling the waters of streams formed by nature, to satisfy the ample needs of the unfertile regions through which they passed. Extensive works of irrigation, secured with an immense amount of labour, skill and science had transformed arid plains into areas of plentiful prosperity at a period when agriculture in Europe was in the crudest and most primitive state. However, these systems fell into disuse consequent to the neglect caused by famine, which resulted from the wars that took place internally and externally. No large irrigation works were constructed after the decline of the Polonnaruwa Kingdom in the 12th century AD, and, until the early 20th century most of the irrigation works were left in ruins over the course of time.

\subsubsection{Policy Objectives}

In the modern era of agriculture successive governments, following the footsteps of the ancestors, have taken large measures in the post independent era to improve the country's food production to meet the demand for its increasing population. In this context the term "self sufficiency in food" has been associated in policy documents as well as in the policy manifestos. The term "Food Security" has come into the literature in the recent past subsequent to the introduction of open economy polices and as a result of the globalization process. The prominence of agriculture is well illustrated in the Report of National Policy Framework for Agriculture, Land and Forestry (Ministry of Agriculture, Land and Forestry, 1995), thus "Paddy (rice) is the staple carbohydrate of the Sri Lankans and its importance to the nation's economy via saving of foreign exchange through import substitution and employment of a large segment of the rural population cannot be overemphasized. About 1.8 million farmers or $10 \%$ of the total population are engaged in paddy cultivation. Rice accounts for $45 \%$ and 40 $\%$ of per capita calories and proteins respectively in the Sri Lankan diet. Hence, food security, by pursuing a policy towards achieving self sufficiency in the major staple, rice, should be a major goal."

This is further reinforced by the diversified agricultural policies adopted by the government in the recent past, in an integrated manner. The new agricultural policy spans a vast area covering environment, biodiversity, infrastructure development, agricultural research, transfer of agricultural and other technologies, input management, crop diversification, domestic \& international trade and so on. Agricultural policy has been aided by a healthy environmental policy being adopted by the Ministry of Environment and Natural Resources (CBSLAR, 2002). Agricultural research has received top priority in the current policy frame and a sum of Rs 100 million has been allocated for this purpose in the budget for 2003. The fund is to undertake research on high priority areas for demand driven research in both private and state sector organizations (CBSLAR, 2002). The marketing infrastructure has been enhanced with the promotion campaign of the Forward Sales Contract System, 
introduced in 1999, among farmers, buyers, policy makers and the general public. Establishment of Dedicated Economic Centres (DEC) at Meegoda \& Embilipitiya is a major break through in providing improved market facilities, which gives immense opportunities for the rural community for better trading in those areas.

The draft policy paper prepared by the Ministry of Agriculture \& Livestock on "National Agricultural Policy and Strategies (NAPS)" has clearly identified many issues, which have serious influence in agricultural productivity. The objective of "NAPS" is to present a series of measures at harnessing and energizing the growth potential in the food crop and livestock sectors to maximize its contribution to economic development. It further asserts that although food security is an important aspect, it cannot be pursued at the cost of increasing domestic food prices.

\subsection{Irrigation Development for Blue Water Agriculture}

The new era of water resources development commenced in the 1930's as a new agricultural policy came into effect, in which irrigation has been the predominant element. Since then a number of irrigation and settlement projects were constructed in the dry zone of Sri Lanka until recent times and this was viewed as one of the most important investment opportunities in the country receiving the support from one political regime after another. Consequent to the introduction of the open economic policy in the country in 1977, the country's economic development direction reached an important turning point. The thrust of the changes was in the direction of reducing government interventions and allowing the market forces to guide the pattern of economic activities. However, in this regime, too, public investment in the irrigation sector received top most priority. During this period the Mahaweli Ganga development scheme was already under implementation on a phased out mode but it was declared as the Accelerated Mahaweli Development Programme use (AMDP), the largest multipurpose water resources development project, in that configuration, having a number of large reservoirs constructed for irrigation and hydropower generation. The main objectives behind these projects were food production towards self-sufficiency and employment generation, reducing population pressure in the wet zone. The irrigation schemes that were developed since 1930 have brought the area irrigated to approximately 536,000 ha by the 2000s, under 98 major (irrigating over 400 ha), 282 medium (irrigating between 80 and 400 ha) and nearly 25,000 minor (irrigating less than 80 ha) irrigation schemes. Accordingly, from the early 1960 s to 2000 s, the area cultivated under major irrigation schemes rose from 200 to 480 thousand hectares, while that in the minor irrigation sector has remained fairly constant and rain-fed agriculture has recorded a decline (see Figure 1).

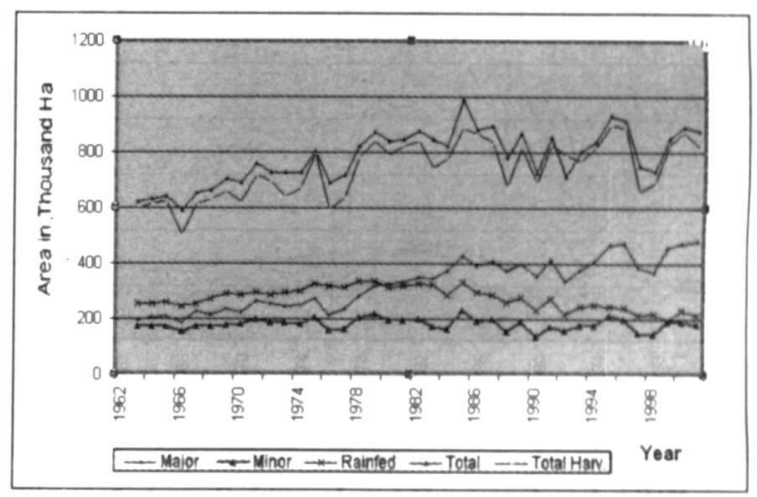

Figure 1. Area Cultivated and Harvested under Different Modes of Irrigation

Source: Department of Census \& Statistics

Pumped irrigation systems too were developed as a complementary activity in most of the irrigation projects in order to cultivate high priced crops. Ground water also has been tapped, especially in small-scale farming, to supplement surface water in minor irrigation schemes, especially in the dry (Yala) season. High rates of return, socially as well as privately, on investments in agro-wells and pumps have encountered their rapid diffusion, making the private investments as major options in tomorrows irrigated agriculture. Large potentials exist for diffusion of agro-wells and pumps in irrigation schemes (Kikuchi $\mathrm{M}$ et el, 2003).

\subsection{Rain fed Agriculture (Green Water) Agriculture}

Rain fed (Green Water) agriculture has been the traditional occupancy in the wet and intermediate zones of Sri Lanka for millennia as 
the climatic, soil and other conditions have been very conducive for farming and the people too had no other choice for their livelihood. A large number of crops (yams, pulses, fruits, spices, and forestry) in addition to rice are grown in these areas, fostering the day to day life of the people. Rice cultivation has been practiced in the lowland area as the two monsoons available to the Island, were very conducive. This huge amount of water (green water) used remains unassessed. In other words, rain-fed agriculture plays a vital role in providing the staples for the rural communities in the regions where even irrigation has been in practice for centuries.

While there is an upward trend in the area cultivated under irrigated conditions there is a marked decline in the area cultivated under rain-fed conditions. The decline is very much prominent in the urbanized wet and intermediate zones due to an unprecedented increase in demand for land for housing and other commercial needs.

A significant increase in land fragmentation in the agricultural sector from 1.8 million holdings in 1982 to 3.3 million holdings in 2002, has taken place in the country during the last two decades as a result of the division of land (DCS, 2002). However, the decline in the land cultivated under rain-fed condition is not felt very much in paddy production because of the substantial increase in production under intensified irrigated conditions with increased yields.

\subsection{Legislative and Management Mechanisms}

There are a large number of Acts, Ordinances and other forms of Enactment; (more than 20) passed long ago for the development, allocation, regulation, usage and management of water resources, in a number of water use sectors. Many of them are either outdated or far too limited to address the issues and problems in the current context of the water use sector. Out of these, the Irrigation Ordinance $(1900,1946)$, Mahaweli Authority Act (1978) and Agrarian Services Act $(1978,1991)$ are the more important legislations, as far as irrigated agriculture is concerned. Implementation responsibility of the Irrigation Ordinance is vested with the Irrigation Department and the District Secretary; the Mahaweli Authority act is vested with the
Mahaweli Authority and the Agrarian Services Act is vested with the Department of Agrarian Services.

Traditionally, operation, maintenance and management of irrigation schemes have been the responsibilities of the farmers, who select a Tract Leader (Vel Vidane, genernlly a land ouner cultivator and oftcn a respected traditional leader) to supervise water deliveries, assign routine maintenance and minor repair works and resolve disputes. His services have been generally appreciated in kind. The responsibility of the Government Agent (District Secretary) was largely confined to arrange cultivation meetings (Kanna Meetings), which constitute the legal binding to resolve delivery disputes and the problems pertaining to land matters. One important fact in Sri Lanka as far as irrigation water is concerned, is that it is given free of charge to the farmers.

Recognizing the importance and the urgent necessity of beneficiary participation in irrigation management, since the early 1980s, the Government of Sri Lanka is seriously committed to implement the concept of beneficiary participation in all phases of irrigation projects: designs, rehabilitation, operation, maintenance and management. Subsequently, in 1989, the Government approved participatory management as a policy; accordingly the Agrarian Services Act was amended in 1991, in order to grant official recognition to farmer organizations. Although this was an important initiative in the correct direction, it did not provide a strategy or guidelines for the Department of Agrarian Services to follow in establishing Farmer Organizations. Even then, some farmer organizations pioneered to carry out the operation, maintenance and management in an effective manner, but are yet to realize the desired situation.

Having realized this situation, the Government of Sri Lanka established the National Water Resources Secretariat in 1996, with the technical assistance received from the Asian Development Bank, Food and Agriculture Organization of the United Nations, and the Government of the Netherlands, in order to prepare the National Water Resources Policy.

Accordingly, the water resources secretariat has studied the issues concerned in the entire water 
use sector and prepared the National Water Resources Policy and institutional arrangements, which has received the approval of the Government in the recent past. This is a timely decision taken by the Government, in order to put the allocation and management of water resources in a more rational and justified direction. The study has considered all the issues pertaining to water resources (both surface and ground) and given a detailed policy including the framework, objectives, scope, policy principles and strategies.

\subsection{Past Performances}

\subsection{Paddy (Rice) Production in Sri Lanka}

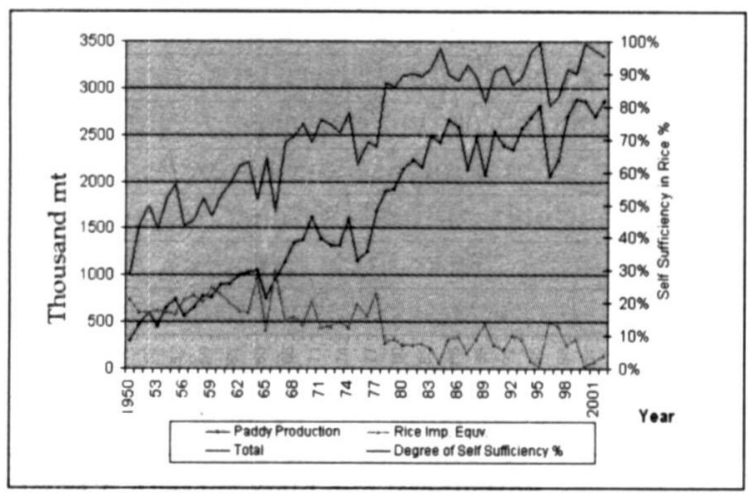

Figure 2. Average Yield and Production Source: CBSLAR 2002-2004, DCS

There has been a steady increase in paddy production from 1952 to date except for a few shortfalls intermittently, due to decline in the area cultivated, caused by droughts. The yield levels have steadily improved over the years and has reached a record value of $4.2 \mathrm{MT} / \mathrm{ha}$ in Yala 2004 for the first time.

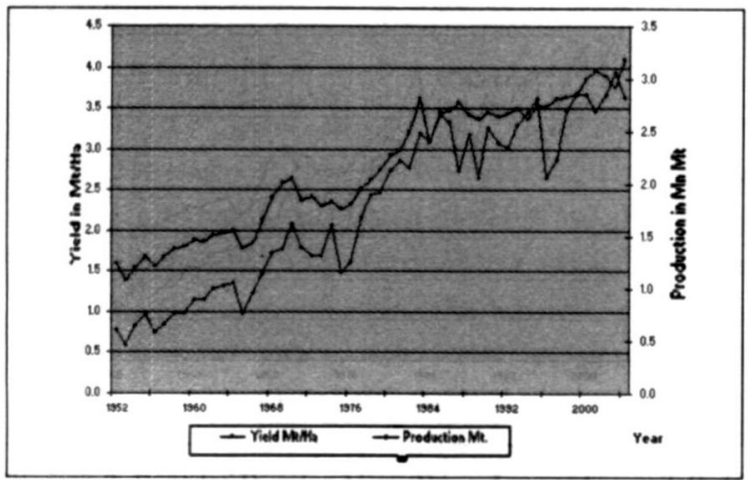

Figure 3 Paddy Production Rice Imports and Self Sufficiency

Source: CBSLAR 2002-2004, Kikuchi et el, 2002
The improvements on the yield levels could be attributed to the use of good quality seeds along with the adoption of the technology package recommended by the Department of Agriculture. Reduction in the extent cultivated due to the scarcity of water during both seasons has eliminated the cultivation of marginal lands, which had a positive impact towards improving the yield.

The above information reflects that irrigated agriculture has been the most important strategic factor in the economic development of Sri Lanka, coupled with the diffusion of seed fertilizer technology. Irrigation development has tremendously contributed to the increase in rice production and, as a result, the import of rice has declined considerably and the degree of selfsufficiency in rice has risen from about $30 \%$ in 1950 s to almost $100 \%$ in 1995, $99 \%$ in 2000 and $98 \%$ in 2003 (see Figure 3). But rice production has declined by $14.4 \%$ in 2004 , compared to the previous year, following a drop of $21 \%$ in the extent cultivated, mainly due to the prevailed drought.

There had been ups and downs in the performance of this sector during the last four decades, but the sector has maintained a steady growth. Despite these achievements, the country's agriculture sector continues to suffer from natural shocks, technology gaps, low investment, and inadequate availability of quality inputs, inadequate funding, transportation and marketing problems, and the lack of a consistent set of trade and tariff policies. The problems are manifested in postharvest losses, low labour productivity, producer unrest, out migration of labour and volatile prices (CBSLAR, 2002).

The current population of the country is around 19.0 million with an approximate household of 4.5 million. The population growth is $1.1 \%$ and the expected population in 2020 would be around 23.0 million. If the same population growth rate and food consumption pattern continue, the country has to secure nearly 2.3 million MT of rice per annum, equivalent to 3.5 million MT of paddy, for which the country has the resources and the potential. Rice will remain as the important part of food security at household level in the foreseeable future. 


\subsection{National Goals and Productivity of Water.}

At national level, development plans on the irrigated agriculture sector are mainly concerned with increased crop production, associated with social and cultural aspirations. This is a broad consolidated goal, which needs to be translated into clearly defined output objectives for system development, management and assessment in order to evaluate the performance. There are many performance indicators defined for this purpose over time and used in different schemes to judge the performance. Cropping intensity, efficiency, relative water supply, uniformity coefficient, equity, variability and productivity of water are some of them.

Abernethy (1985) uses uniformity coefficient and productivity of water as performance indicators in the Kaudulla study and reports $0.355 \mathrm{~kg} / \mathrm{m} 3$ productivity of water corresponding to a paddy yield of $3.93 \mathrm{t} / \mathrm{ha}$. $\mathrm{He}$ suggests $0.5 \mathrm{Kg} / \mathrm{m} 3$ as a modest target for productivity of water, for irrigation schemes in Sri Lanka.

Bird (1994) reports from the Hakwatuna Oya water management study, an approximate yield of $4.38 \mathrm{t} / \mathrm{ha}$ (direct results from crop cutting were $5.5 \mathrm{t} / \mathrm{ha}$ ) in Maha 90/91 against the provincial average of $3.35 \mathrm{t} / \mathrm{ha}$. This corresponds to productivity of water as $0.58 \mathrm{~kg} /$ $\mathrm{m} 3$, which is quite impressive and encouraging, against the target set by Abernethy and this forms a realistic basis for the planners.

Imbulana and Merrey (1995) have analyzed the performance of four irrigation schemes from 1990-1993, and reports the highest productivity of $0.308 \mathrm{~kg} / \mathrm{m} 3$ realized in the Maha season in the Parakrama Samudra scheme.

Table 1. Productivity of water on different irrigation schemes.

\begin{tabular}{|c|c|c|c|}
\hline Indicator & $\begin{array}{c}\text { Abernethy } \\
\text { (1985) }\end{array}$ & $\begin{array}{c}\text { Bird } \\
\text { (1994) }\end{array}$ & $\begin{array}{c}\text { Imbulana } \\
\text { \& Merrey } \\
\text { (1995) }\end{array}$ \\
\hline $\begin{array}{l}\text { Period of } \\
\text { study }\end{array}$ & $1978-83$ & 1988 - 92 & $1990-93$ \\
\hline $\begin{array}{l}\text { Productivity } \\
\text { of water } \\
\mathrm{kg} / \mathrm{m} 3\end{array}$ & 0.355 & 0.58 & 0.308 \\
\hline Yield kg/ha & 3.93 & 4.38 & 4.36 \\
\hline
\end{tabular}

Productivity of $0.5 \mathrm{~kg} / \mathrm{m} 3$ as suggested by Abernethy, seems to be a reasonable target, which can be achieved in most of the irrigation schemes in Sri Lanka, in an average season without any unusual drought. A yield of $4.4 \mathrm{t} /$ ha at current market price of paddy, is a profitable output for an average farm family, that has at least a hectare of cultivable land and some kind of off-farm income also to support their life.

\subsection{Adverse Impact of Irrigated Agriculture on Environment}

The overall perception about irrigation development to enhance food production, among the majority of the general public has been very poor in the past, confining only to the extent of meeting their short-term needs. The considerable regard and pervasive feeling about water and environment, that had existed, based on religious and cultural heritage, for ages, got eroded during the last few decades under the increasing pressure of poverty, mismanagement of natural resources and unplanned development activities. This could have resulted due to political reasons, lack of knowledge \& technology, lack of funding or even due to ignorance. Whatever the reason, this may' end up in destruction of development and ecosystem in the long run. It is impossible to consider water, environment and development, singly, in isolation, as they individually and collectively interact eternally. Under natural conditions they are mutually dependent on each other and separation is impossible.

The investment in the irrigated agriculture sector has resulted in increased benefits, but productivity response and sustainability of irrigation systems have been constrained by salinity, water logging, low yields, lower prices and poor markets. The discharge of effluents containing suspended solids, nitrates and phosphates cause marked changes in the ecology of the receiving water. The use of agrochemicals and fertilizers in agricultural and farming activities, have created considerable changes in the quality of return water, biodiversity, aquatic ecosystems and change of soil properties. Further, soil erosion and overexploitation of natural resources are the other adverse effects caused by this sector. Deterioration of the quality of groundwater also 
has been reported from many parts of the country. Sustainability of food production mainly depends on the sound and efficient water use and conservation practices, primarily in irrigated and in rain-fed agriculture, and also in livestock, inland fisheries and agro forestry. Therefore, the current subsistence agriculture needs to be transformed into an environmentally sustainable, productive and economically viable venture in order to ensure food security.

\section{Future of the Water Resources ${ }^{(1)}$ Sector}

\subsection{Trend for New irrigation Projects}

Irrigation development means large investments and recurrent expenses, substantial energy requirement for pumping water, loss of large areas of land and waste of diverted water. This is why the investment on new irrigation development is not gaining much attraction of investors and forcing water professionals even to consider the withdrawal of water that is being used for agriculture right now. The low rice price since the collapse of the commodity boom in the mid 1980s discouraged the government and international donor agencies from investing in new irrigation construction.

Since the investment in new irrigation projects indicates negative returns, modernizing the existing infrastructure for improved performance in water deliveries, better water saving agricultural practices and for improved on-farm water management, are very essential to achieve productivity gains. Irrigation technology needs to be upgraded while water management has to become more serviceoriented and cost effective with user participation for which capacity building of the institutions would be the most attractive alternative

Modernizing and diversifying the agriculture sector through increased investment is another potential area where a substantial improvement can be realized. The traditional food commodities offer a limited scope for increasing returns to intensified investments. Therefore, the sector needs to explore the possibilities to increase return through prioritization and diversification in order to attract the commercially oriented private sector investment.
Also introducing agricultural implements with low cost technologies is an important area to be focused, since the productivity of labour in agriculture is very low.

However, any new irrigation development has to be accompanied by environmental impact assessments, the extent of which will depend on the scope of the project and the potential negative impacts. Also, the proposals for such schemes should consider more rational exploitation of natural resources, increased water use efficiency and productivity. The technologies employed in such a proposal should be thoroughly evaluated, including their potential conflicts with other land and water uses.

\subsection{Future Options}

Based on the drawbacks experienced by the irrigated agriculture sector at home, one can argue that Sri Lanka has no comparative advantage in producing rice at a higher cost whereas it can be purchased at a lower price. This argument holds true as long as the market conditions are perfect and the farmers who are getting expelled from paddy cultivation have alternate employment elsewhere. Although open economic policies are in operation for more than two decades in Sri Lanka, it has not developed to a level where aspirations of the water use sectors can be achieved.

On the other hand, the heavy investment made in developing irrigation infrastructure, not only using local funds but also on borrowed funds, during the last half a century, merely to achieve self sufficiency in rice cannot be simply overlooked in the light of liberalized economic policies. This was the major reason for the rice prices to decline in the international market, due to increased production, which largely reflects the success of global and domestic strategies adopted to ensure food security.

Under the circumstances, countries like Sri Lanka are compelled to continue with the current agricultural programme in order to ensure food security, employment opportunities and poverty alleviation.

\subsection{Future of Irrigated Agriculture}

Irrigated agriculture will continue to play the dominant role in feeding the nation in spite of 
the shortfall discussed above. Also agriculture continues to be the country's largest water user in terms of volume, with relatively low efficiency. Further low labour productivity in agriculture and relatively high cost of fertilizer and agro-chemicals do not allow the cost of rice production to come down. Labour wages have increased much faster than productivity in this sector and lags far behind the productivity in the industrial and service sectors. Under the circumstances, the domestic agricultural sector, especially the rain fed, is already facing a decline in extent cultivated and in the yield. In the future, the irrigated agriculture sector has to be more conscious with regard to the efficiency of water use, labour productivity; crop technology and the environmental issues in order to bring down the cost of production and to make the sector lucrative.

This will necessitate enhanced investments in modernizing the existing irrigation infrastructure, improved operation and maintenance and introducing new technologies, which are obviously capital intensive but under liberalized economic conditions. Private sector participation would be an appropriate and feasible solution to face the challenges. A viable response to the falling productivity in this sector is to establish an intense research and extension service aiming at enhancing productivity.

\subsection{Future Challenges}

\subsubsection{Community Water Supply and Industry}

The population in Sri Lanka is expected to be around 23.0 million in 2020 against 18.7 million in 2001. With the increasing population, industrialization and urbanization, demand for clean water will increase in the future considerably. An incremental demand for community water also will be unavoidable with increasing levels of sanitation practices. The National Water Supply \& Drainage Board and other local authorities will have to face many challenges in the coming years to improve the coverage and the level of service. The NWS\&SB intends to increase their coverage to $85 \%$ in year 2010 by a multifaceted development programme.

In implementing this plan the National Water Supply \& Drainage Board has to have an integrated approach, which falls in line with policies laid down by the National Water
Resources Council., as there can be incidents arising out of conflict of interest and other operational problems. Any community water supply project implemented in the dry zone will create a demand on water that is being used by the irrigation sector. Sharing water resources will be a major task in this exercise in order to satisfy the needs of everyone. Also, attention should be focused on using low water consuming household appliances in order to optimize the usage.

\subsubsection{Industrial Sector}

Future economic growth envisages a considerable expansion in the industrial sector, which will create more demand for water. The industrial sector will have to be extremely cautious in drawing water from whatever the source, as these sources are already in a stressed condition. Any excessive withdrawal can lead to salt water intrusion, lowering water tables, depletion of groundwater reserve and pollution of both sources, in addition to the pressure imposed on other uses. On the one hand, the sector has got to opt for low water consuming technology and on the other, minimize effluent discharge into the water bodies. Waste water and effluents should only be discharged after proper treatment. "Withdraw less and pollute less" will be the best approach to manage the crisis.

\subsubsection{Irrigated Agriculture}

The available water resources for agriculture in the country are diminishing gradually and this sector will face increasing competition for water from industrial and domestic users. The efficient use of water in agriculture will be the key element in achieving enhanced productivity gains as well as saving water for other uses. Also in water scarce areas, instead of rice, less water consuming, commercially viable crops, which have an export market, have to be promoted, so that at least a part of the import bill for rice could be recovered.

The major challenges confronted by this sector are

(a) Divert, withdraw and consume less water leaving an opportunity for other water users. 
(b) Improve the quality of irrigation services, in terms of adequacy, reliability and timeliness and reduce the real cost of providing irrigation services

(c) Introduce improved irrigation application methods to improve the water use efficiency and improved crop management technology to enhance food production.

(d) Minimize environmental degradation by

(i) Lowering water tables and reducing root zone salinity and

(ii) Minimizing the pollution of return flows

\subsection{Recommended Approach}

In the overall perspective the infrastructure (hardware component) developed for agriculture and the country's resources have the potential to feed its population today and in the future and most of the institutional arrangements and the policy guidelines for this are in place. What is mainly and urgently required is the political will to mobilize the necessary financial and other resources with good governance, user participation and commitment. Most investment in agriculture derives benefits in the long run and, therefore, the policies governing this sector have to be firm, well specified, consistent with that of trade, environment, and should be made known to all stakeholders in order to crowd in private sector investment.

The dissemination of already developed technologies to the farming communities through an intensified extension network is a vital process in enhancing productivity. Also more research is required in using fertilizer, agro chemicals and other inputs in order to reduce the cost of production. A substantial cost reduction in agriculture could be achieved by using organic fertilizer and this need to be encouraged. Higher yield crop varieties should be developed and distributed in order to increase the yields since there is considerable potential for improvement. Also action should be taken to promote cultivation of high quality rice for the export market in areas where assured water and other resources are available.

Strategies implemented to enhance food production in the country have to be coupled with integrated rural development inclusive of agriculture, staple food as well as other field crops, livestock, inland fishery and other industries in order to enhance diversified income for the farmers. This has to be backed by a well-constructed regulatory framework and stronger user participation at all levels with required legal backing. Fostering this approach through dedicated commitment of all the sectors (political, private, GOs, NGOs and civil groups) is very vital in realizing the desired benefits.

Agriculture is exposed to all natural shocks and erratic changes of climate and therefore uncertainty plays a major role in accruing benefits. In the case of industry, uncertainties can be controlled and the production target can be achieved most of the time. Though agriculture is the poorer sector in the developing countries, it produces food to kill the hunger of all people. It should be patronized and supported by all others

\subsection{Conclusions}

Agriculture will continue to be the main livelihood of the rural population of the Island, because, on the one hand they have to feed themselves and the urban population and on the other there is no other suitable livelihood which could accommodate such a work force. Rice will remain as the staple food of the nation especially, the rural masses in the foreseeable future. The country has the required resources to produce the food for the current population as well as that of the future at least for the next two decades. Also, the required infrastructure is in place with heavy investment made using local as well as borrowed resources.

Currently the agricultural sector uses a large amount of water with low productivity. The sector will face severe challenges in the future, in the light of diminishing fresh water resources and increasing demand for the same posed by the increasing population associated with improved living standards and urbanization. This will be further aggravated by the demand created by the industrial sector that contributes to economic growth in the urban as well as in the rural sector.

This situation exerts a strong pressure on the irrigated agricultural sector to enhance the productivity of water and release a part of the 
water used for agriculture to other sectors. Enhancing the productivity of water demonstrates many pre requisites, updating \& modernizing the irrigation infrastructure, introducing modern irrigation technology, efficient system operation and management, use of improved varieties of seeds and other inputs, minimizing energy costs, application of improved farming technology and many more.

Further, a much needed action is to create awareness among the water users (Irrigation, domestic, industry, etc.) on the current status of this sector, economic aspects of water resources development, scarcity for capital, diminishing nature of freshwater resources, adverse consequences of wasting developed water and more than anything the cost of not having water when it is needed. This needs to be fostered by the government organizations, non government organizations, civil society, private sector and even the religious organizations. Water crisis must be given equal publicity as the energy crisis.

Although water ${ }^{(2)}$ is becoming an economic commodity it must be treated as a social, cultural and environmental resource by giving due considerations to the pervasive values which has existed for millennia in this country, because water is life blood of the world and there is no substitute for it.

\section{References}

(1) Abernethy, C. L (1985). Irrigation Water Management at Kaudulla, Sri Lanka: a review of measurements in 1978-83 and a proposal for new management methods. HR Wallingford Report No OD 70

(2) Arumugam S (1969), Water Resources of Ceylon. Water Resources Board.

(3) Bird JD (1994). Hakwatuna Oya Water Management Study, Sri Lanka: Summary Report, HR Wallingford Report No OD 127.

(4) Brohier RL (1979). Ancient Irrigation Works in Ceylon, The Ministry of Mahaweli Development, Colombo, Sri Lanka

(5) Central Bank of Sri Lanka, Annual Reports, 2002, 2003,2004

(6) Department of Census and Statistics, Various Reports

(7) Imbulana K A U S, and Merrey D J, (1995) Impact of Management Interventions on the performance of five irrigation systems in Sri Lanka. IIMI, Colombo

(8) Kikuchi et el, 2002, Irrigation Sector in Sri Lanka, Recent Investment 5. Trends and the development Path Ahead, IWMI, Colombo

(9) Water Resources Council \& Secretariat, (2000). National Water Resources Policy and Institutional Arrangements, Colombo.

(10) Zainudeen, M Y (2001), Water Resources Engineering and Management for Rural Communities, the Challenges for Agriculture, and other Water Users in Sri Lanka In the 21st Century, "Engineer" IESL, Colombo.

(11) Zainudeen, M Y (2005), Strategies to Address The National Food Security And Environmental Sustainability In The Context Of Changing Climate And Global Trade Rules. "Engineer" IESL, Colombo. 